\title{
PRIMER UPORABE GIS PRI ISKANJU MOŽNIH VIROV ONESNAŽEVANJA VODE NA KRASU
}

\author{
Marko Krevs in Igor Jurinčič
}

UDK 91:881.3:628.19

Pouzetek

Geografske informacijske sisteme lahko koristno uporabimo tudi na delounih področjih, kjer nimamo na razpolago useh ustreznih podatkov, metod za njihovo vrednotenje ter modeliranje. Takšen primer je tudi pomoč GIS pri iskanju možnih virov onesnaževanja na krasu.

Razen redkih pouršinskih vodotokov (na fluviokrasu) se tam vode pretakajo po podzemlju. Zato moramo prisotnost krasa v zaledju pouršinskega vodotoka obravnavati na "poseben" način, pri čemer nam je GIS v veliko pomoč. GIS je $v$ tem primeru dejansko podpora deduktivnermu pristopu k obravnavi problema.

$Z$ upoštevanjem "kraških predpostauk" glede možnega pretakanja podzemskih voda se območje možnih virov onesnaževanja znatno razširi preko meja pouršinskega porečja. Na podlagi vrednotenja upoštevanih predpostavk, podatkounih slojev in njihovih medsebojnih relacij sva ločila tri "območja ogrožanja kvalitete vode" otavščice. Ta lahko služijo za načrtovanje in izvajanje nadaljnjih ukrepov za rešitev problema.

Izvajanje aplikacije na prenosnem osebnem računalniku omogoča njeno uporabo pri terenskih meritvah ter pri terenskem iskanju in popisovanju dejanskih virov onesnaževanja.

$V$ obravnavo je vključeno 255 kvadratnih kilometrov veliko območje jugozahodnega obrobja Ljubljanskega Barja (širša okolica porečja Otavščice, pritoka Borouniščice).

UDC 91:881.3:628.19

Abstract

THE APPLICATION OF GIS FOR SEARCHING POSSIBLE SOURCES OF POLLUTION ON THE KARST

Geographic Information Systems can also be fruitfully applied for solving problems when all the necessary data and methods for their evaluation and modelling are not available. Such an example is represented by the support of GIS in searching possible sources of pollution on the karst.

The waters on the karst normally flow underground, except for some rare superficial waterflows on the fluviokarst. This is the reason to treat in a special way the presence of karst in the hinterland of a superficial waterflow. In such a case GIS is a support to the deductive appraach in solving the problem.

Application of "karstic assumptions" about possible underground waterflow

Marko Krevs, dipl. geogr., Igor Jurinčič, dipl. geogr., Oddelek za geografijo, Filozofska fakulteta, Univerza v Ljubljani, Aškerčeva 12, 61000 Ljubljana 
connections can substantially enlarge the area of possible locations of pollution sources beyond the borders of hypsographic (superficial) river basin. Three categories of areas endangering the water quality of the Otavščica brook have been derived from the data layers, assumptions, and their interaction. They can serve us as a basis for the planning and execution of further actions to solve the problem.

The application is running on a portable PC. This enables its use in field work, including the search and registration of actual sources of pollution.

In our study an area of 255 square kilometers (wider surroundings of Borouniški Pekel, southwest of Ljubljana) has been taken into consideration.

Skoraj praviloma GIS načrtujemo in izdelujemo za področja dela, kjer so zanesljivi podatki predpostavka, potrebna znanja in orodja za vrednotenje, ki je podlaga za določene ugotovitve in morda odločitve, pa že izdelana in preizkušena.

Vedno pa bomo imeli tako raziskovalci, kot operativne službe, opravka z nekaterimi prostorskimi problemi, za katere zgornje "zahteve" ne bodo izpolnjene, uporaba GIS pri njihovem reševanju pa bo vendarle lahko pripeljala do koristnih ugotovitev ali ustreznih ukrepov.

Primer takšnega problema je tudi iskanje možnih virov onesnaževanja na krasu. Razen redkih površinskih vodotokov (na fluviokrasu) se tam vode pretakajo po podzemlju. Podrobnih meritev smeri, količin in hitrosti teh podzemnih tokov za velik del krasa nimamo na razpolago. $\mathrm{Za}$ onesnaževanje so pomembni tudi majhni, hidrogeološko "nepomembni" tokovi. Poleg tega ugotovitve kažejo, da se vode podzemno lahko raztekajo $v$ več smeri hkrati, na različnih globinah hkrati ter $\mathrm{v}$ različne smeri ob različnih hidro-meteoroloških razmerah (Gams, 1974; Gospodarič \& Habič, 1976). Zato moramo prisotnost krasa v zaledju površinskega vodotoka obravnavati na "poseben" način, pri čemer nam je GIS v veliko pomoč. GIS je $v$ tem primeru dejansko podpora deduktivnemu pristopu $k$ obravnavi problema (slika 1).

\section{DEDUKCIJA IN GIS PRI REŠEVANJU PROSTORSKEGA PROBLEMA}

Dedukcija temelji na poznavanju dosedanjih preučevanj obravnavane problematike. Ker podzemnega pretakanja vode, ki poleg površinskih voda prenaša onesnaženje, na obravnavanem območju praktično ne poznamo, si lahko pomagamo le s splošnejšimi znanji o kraških vodah. Ta lahko poenostavljeno predstavimo tako, kot kaže slika 2 na shematičnem prečnem prerezu obravnavanega območja.

Podlaga nadaljnjemu razmišljanju je teoretična možnost, da je na krasu mogoč podzemni dotok vode $\mathrm{s}$ površja in iz podzemlja, ki sta po nadmorski višini nad neko točko (npr. nad vodoravno črto, ki bi jo lahko na sliki 2 potegnili skozi prerez struge potoka, če je slednja točka možnega podzemnega dotoka vode). Ker tudi na fluviokrasu (na dolomitni podlagi) najdemo vrtače, ki so kazalec vertikalnega pretakanja, lahko teoretično možnost podzemnega pretoka razširimo tudi na ta območja. 
Slika 1: GIS za podporo deduktivnemu reševanju prostorskega problema.

PROBLEM: ugotovljeno onesnaženje vode na določeni točki vodotoka na krasu (ali v njegovi neposredni bližini) - kje naj iščemo vire onesnaženja

manjkajoči bistveni podatki

"splošno" strokovno znanje o krasu

"kraške predpostavke" o podzemnem pretakanju vode

dedukcija

ugotavljanje prostorskih razsežnosti veljavnosti

GIS

"kraških predpostavk"

- upoštevanje številnih drugih podatkovnih slojev za obravnavano območje

- opredelitev podobmočij $\mathrm{z}$ različno stopnjo možnega ogrožanja kvalitete vode $\mathrm{v}$ obravnavanem vodotoku

informacije pred odhodom na teren oziroma smernice za terensko delo

GIS

na terenu najdenih virov onesnaževanja in njihovimi atributi

- vrednotenje izpopolnjene podatkovne podlage za reševanje problema *

* Ta del metodologije in GIS - aplikacije še ni izdelan. 
Slika 2: Splošne značilnosti pretakanja vode na krasu (prerez).

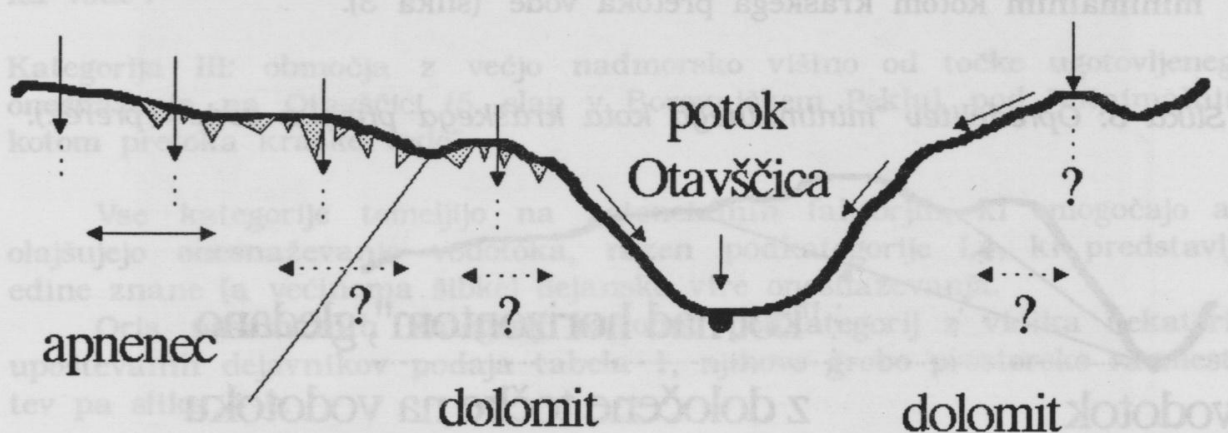

$\begin{array}{ll}\longrightarrow & \text { padavine, znano površinsko in podzemsko } \\ \text { pretakanje vode } \\ ? \quad \text { nepoznano, a možno podzemsko pretakanje vode } \\ \square \quad \text { vrtače }\end{array}$

V obravnavo je vključeno 17 krat 15 kilometrov veliko območje jugozahodnega obrobja Ljubljanskega Barja (širša okolica porečja Otavščice oziroma Borovniškega Pekla). Za izdelavo podatkovnih slojev sva uporabila: digitalni model reliefa (celice $100 \times 100$ metrov), podatke o prebivalstvu, kmetijstvu, industriji, turizmu in počitniških bivališčih, topografske, vegetacijske in geološke karte. Poleg omenjenih (manjkajočih ali pomanjkljivih) hidrogeoloških meritev bi potrebovala še evidenco onesnaževalcev in odlagališč odpadkov (zlasti industrijskih).

Preglejmo posamezne upoštevane elemente, ki so pomembni pri onesnaževanju vode, prenosu onesnaženja vode, oziroma pri odlaganju za kvaliteto vode potencialno nevarnih odpadkov.

1. Relief in litologija: na območjih apnenca je kras; na dolomitnih območjih najdemo kraške in fluviokraške oblike površja. Fluvialni relief $z$ normalnim vodnim odtokom je obkrožen s kraško planoto (kraški pretok) in dolomitnimi vzpetinami (fluviokras).

2. Vrtače: tipične kraške oblike, še posebej "primerne" in zelo pogoste lokacije trdnih in tekočih odpadkov. Kazalec vertikalnega (podzemskega) vodnega odtekanja.

3. Hipsografsko (površinsko) porečje: območje prevladujočega površinskega odtoka vode $\mathrm{v}$ določeni vodotok.

4. Kraško porečje: območje podzemskega pritakanja vode v obravnavani vodotok. Zaradi pomanjkanja podatkov o podzemnem pritoku govorimo o "potencialnem kraškem porečju" (PKP). To je območje možnih vertikalnih in horizontalnih podzemskih vodnih dotokov. Skrajne meje PKP določa meja sklenjenega območja, ki se nahaja nad točko vodotoka, na kateri je ugotovljeno onesnaženje. 
Območje bolj verjetnega kraškega dotoka vode znotraj PKP je določeno z "minimalnim kotom kraškega pretoka vode" (slika 3).

Slika 3: Opredelitev "minimalnega kota kraškega pretoka vode" (prerez).

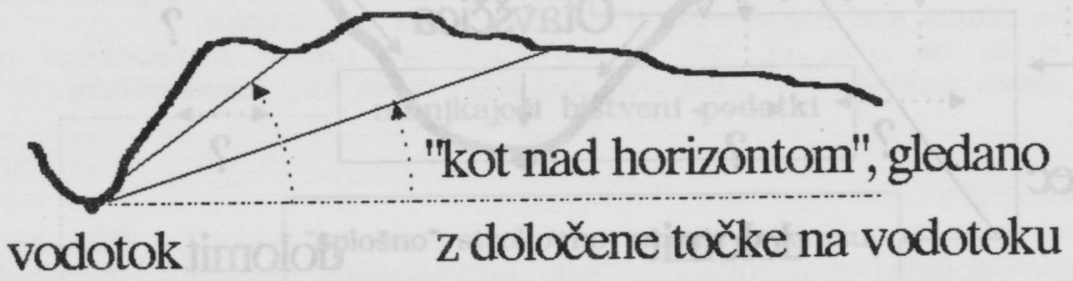

Pojasnilo: "kot nad horizontom" gledano s točke na vodotoku enak $2^{\circ}$ je "minimalni kot pretoka kraške vode". Zgolj "orientacijska" vrednost, ki označuje mejo območja, kjer je podzemski pretok bolj verjeten (kjer je kot večji od $2^{\circ}$ ).

5. Rastje: gozdnata območja so obravnavana kot še posebej "privlačna" in "varna" za odlaganje odpadkov.

6. Prebivalstvo: je neenakomerno in na redko posejano po vaseh. Značilen je proces depopulacije.

7. Gospodarstvo: opuščanje kmetijstva (neugodne naravne razmere, ostarelo prebivalstvo), le nekaj živinoreje. Industrija v zaledju obravnavanega območja povzroča ekološke probleme. V bližini so poznana "črna" odlagališča industrijskih odpadkov iz nekaterih tovarn (Bricelj, 1983).

8. Populacijski ekvivalenti (PE) onesnaževanja: opredeljeni po naseljih na podlagi podatkov o prebivalstvu, živini, kmetijski mehanizaciji, turizmu in gostinstvu, počitniških bivališčih in industriji.

9. Cestno omrežje: opredeljuje dostopnost do lokacij, ki so privlačne za odlaganje odpadkov.

$\mathrm{Na}$ podlagi podatkov, predpostavk in njihovih medsebojnih relacij sva določila tri kategorije območij možnih lokacij virov onesnaževanja vode. Prva med njimi kaže na območja, ki potencialno ali dejansko najbolj ogrožajo kvaliteto vode obravnavanega vodotoka.

Kategorija I: sklenjeno območje nad "minimalnim kotom kraškega pretoka vode", na katerem je prisoten vsaj eden izmed naslednjih elementov: apnenec, vrtače ali hipsografsko porečje. Območje še naprej delimo (proti bolj ogrožajočim oziroma bolj "občutljivim" območjem) na:

1) območja travnikov in pašnikov,

2) območja gozdov,

3) območja, ki so manj kot 100 metrov oddaljena od cest,

4) območja, ki so manj kot 500 metrov oddaljena od naselij,

5) območja I.3 ali I.4, ki se prekrivajo s 100 metrskim pasom ob Otavščici. 
Kategorija II: vsa ostala območja nad "minimalnim kotom kraškega pretoka vode".

Kategorija III: območja $z$ večjo nadmorsko višino od točke ugotovljenega onesnaženja na Otavščici (5. slap v Borovniškem Peklu), pod "minimalnim kotom pretoka kraške vode".

Vse kategorije temeljijo na potencialnih faktorjih, ki omogočajo ali olajšujejo onesnaževanje vodotoka, razen podkategorije I.4, ki predstavlja edine znane (a večinoma šibke) dejanske vire onesnaževanja.

Oris posameznih kategorij oziroma podkategorij $z$ vidika nekaterih upoštevanih dejavnikov podaja tabela 1 , njihovo grobo prostorsko razmestitev pa slika 4 b.

Tabela 1: Izbrani opisni podatki za posamezne kategorije ogrožanja kvalitete vode $v$ Otavščici.

\begin{tabular}{|l|r|r|r|r|r|r|r|}
\hline & \multicolumn{3}{|l|}{ Kategorije } \\
\hline & 1.1 & 1.2 & 1.3 & 1.4 & 1.5 & 11 & 111 \\
\hline A)Povrsina (ha) & 155 & 1629 & 352 & 522 & 17 & 3702 & 6820 \\
\hline B)Povprecna relat ivna visina nad slapom (m) * & 170 & 179 & 165 & 194 & 158 & 253 & 70 \\
\hline C)Povprecna oddal jenost od vodatoka nad slapom (m) & 1560 & 1646 & 2405 & 1079 & 76 & 2520 & 5153 \\
\hline D)Povrs je na apnencu (x) & 67 & 36 & 57 & 17 & 0 & 6 & 83 \\
\hline E)Povrsje z vrtacami (x) & 26 & 39 & 75 & 27 & 6 & 1 & 70 \\
\hline F)Povrs je poraslo z gozdom (x) & 0 & 100 & 97 & 52 & 88 & 69 & 85 \\
\hline G)Povprecna oddal jenost od cest (m) & 532 & 611 & 64 & 237 & 116 & 593 & 374 \\
\hline H)Povprecna oddal jenost od naseli j & 964 & 1473 & 1502 & 300 & 1175 & 839 & 2024 \\
\hline 1)Vsota populaci jskih ekvivalentov onesnazevanja (PE) & 0 & 0 & 0 & 1980 & 0 & 3589 & 3770 \\
\hline
\end{tabular}

* Nadmorska višina 5. slapu na Otavščici v Borovniškem Peklu je 560 metrov.

\section{ZAKLJUČKI}

Predstavljene izkušnje bodo lahko koristne, saj za zelo velik del krasa ne bomo imeli kmalu na razpolago vseh podatkov, ki jih potrebujemo za reševanje tovrstnih problemov. Rezultati lahko služijo za načrtovanje in izvajanje nadaljnjih ukrepov za rešitev problema.

Hidrogeološko modeliranje pretakanja kraških voda še vedno ostaja izven našega metodološkega dosega. $Z$ uporabo podrobnejših podatkov $o$ kraškem pretakanju vode, o njeni kvaliteti, katastrskih podatkov o odlagališčih odpadkov in drugih onesnaževalcih, pa bi lahko izkoristili že obstoječe znanje za posredovanje nekaterih potrebnih informacij ustreznim ustanovam in prebivalstvu. Med drugim bi lahko natančneje opredelili območja možnega ogrožanja kvalitete vode ter podali podrobnejše ukrepe 
Slika 4: Orientacijska karta obravnavanega območja (a) in poenostavljena karta območij po kategorijah ogrožanja kvalitete vode $v$ Otavščici (b).

a)

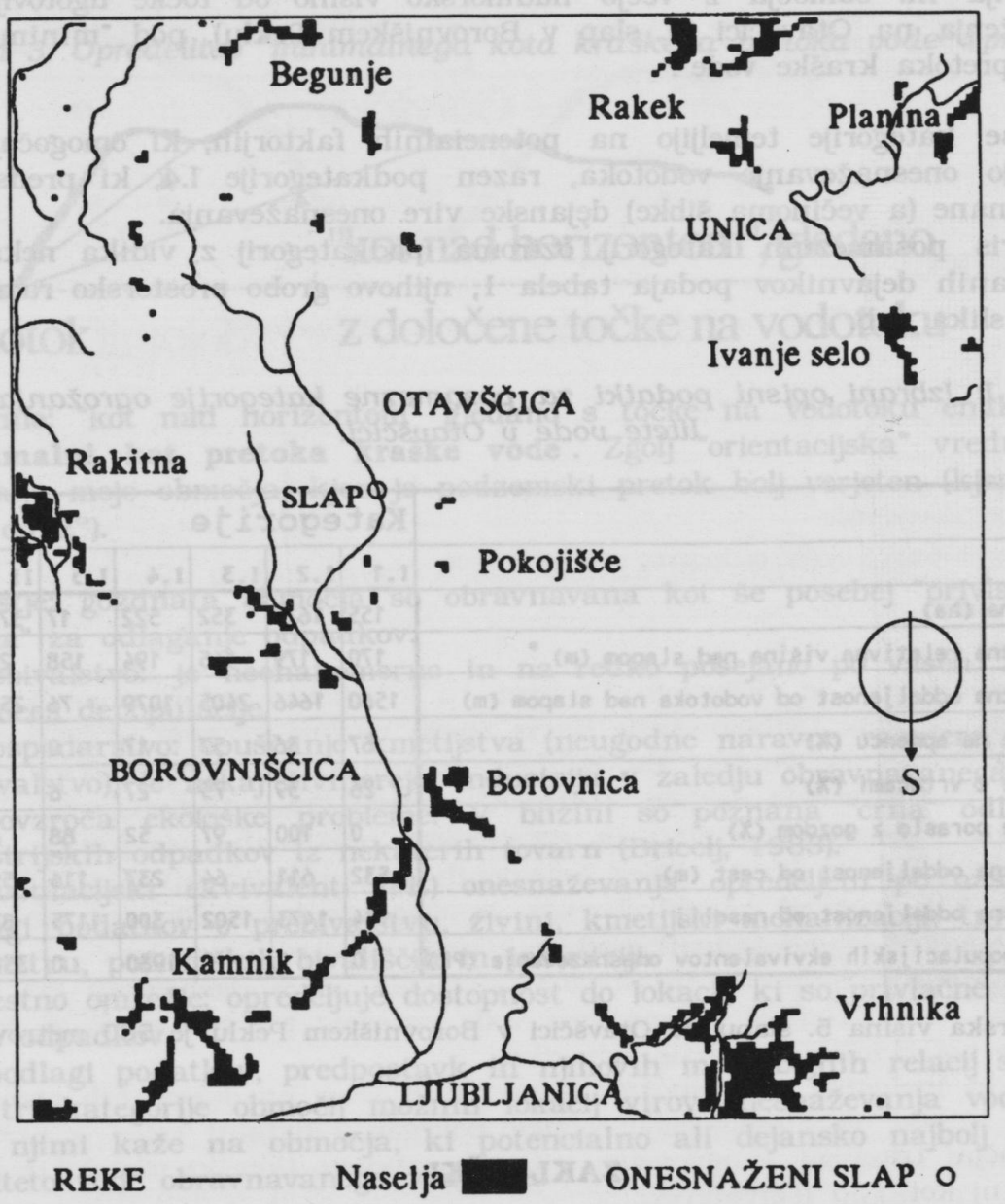

in navodila za preprečevanje onesnaževanja iz kmetijstva, industrije, prometa in turizma. 
b)
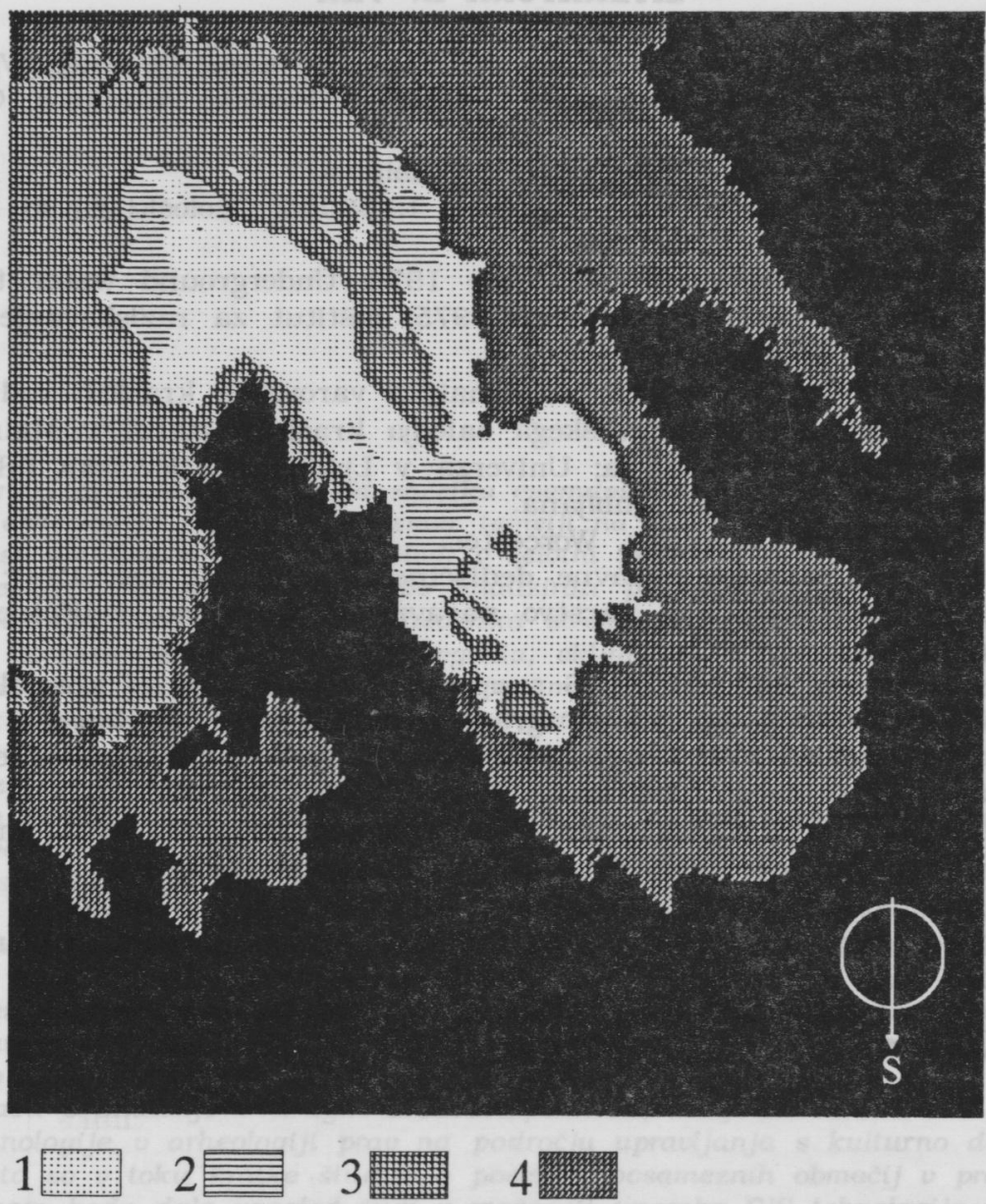

1-območja travnikov, pašnikov (I.1) in gozdov (I.2) ter območja, ki so manj kot 100 metrov oddaljena od cest (I.3)

2 - območja, ki so manj kot 500 metrov oddaljena od naselij (I.4), območja I.3 in I.4, ki se prekrivajo s 100 metrskim pasom ob Otavščici (I.5)

3 - vsa ostala območja nad "minimalnim kotom kraškega pretoka vode" (II)

4-območja $z$ večjo nadmorsko višino od točke ugotovljenega onesnaženja, vendar pod "minimalnim kotom pretoka kraške vode" (III) 


\section{LITERATURA IN VIRI}

Bricelj, M., 1983: Degradacija okolja na primeru Industrije usnja Vrhnika; Diplomska naloga; Univerza v Ljubljani, Filozofska fakulteta, Oddelek za geografijo, Ljubljana.

Gams, I., 1974: Kras; Slovenska matica, Ljubljana.

Geološka karta Slovenije, 1967; Postojna, 1:100000; Geološki zavod Ljubljana.

Gospodarič, R. \& Habič, P. (Editors), 1976: Underground water tracing, Investigations in Slovenia 1972-1975; Inštitut za raziskovanje krasa ZRC SAZU, Postojna, Slovenija.

Hrvatin, M., 1991: Geografska problematika varovanja kraških vodnih virov, Na primeru hidrografskega zaledja kraških izvirov v Malnih pri Planini; Diplomska naloga; Univerza v Ljubljani, Filozofska fakulteta, Oddelek za geografijo, Ljubljana.

IDRISI, 1991: Clark University, Worcester.

Inventar najpomembnejše naravne dediščine Slovenije, 2. del; 1991; Zavod republike Slovenije za varstvo naravne in kulturne dediščine, Ljubljana.

Jurinčič, I., Krevs, M., 1992: GIS supports the searching of possible sources of pollution on karst; gradivo mednarodne konference "GIS From Space to Territory, Theories and Methods of Spatio-Temporal Reasoning in Geographic Space", Pisa, Italija.

Prvi začasni podatki popisa prebivalstva, gospodinjstev, stanovanj in kmečkih gospodarstev 1991; Zavod RS za statistiko, Ljubljana.

Statistični letopis Slovenije, 1981: Zavod RS za Statistiko, Ljubljana.

Topografska karta Slovenije, 1975: 1:25000; Vojnogeografski inštitut, Beograd.

Vegetacijska karta Slovenije; 1975; Postojna, 1:100000; Biološki inštitut Jovana Hadžija, SAZU, Ljubljana. 